\title{
Uji Publik Sebagai Model Pelibatan Masyarakat Dalam Seleksi Komisioner Komisi Pemberantasan Korupsi
}

\author{
Fauzin \\ Fakultas Hukum Universitas Trunojoyo Madura \\ fauzin@trunojoyo.ac.id
}

Submit: 15-06-2020; Review: 15-06-2020; Terbit: 15-06-2020

\begin{abstract}
The purpose of the study is to determine the role model of community involvement in the selection of eradication commissioners. It is considered important for it lead to pro and contra among community; including the eradication commisioner selection result for 2019 - 2023 period. Moreover, the previous selection creates a curious attention. Two period of selection ( 2007-2011 and 2011-2015) shows that some eradication commisioners entangled in a legal case that results in a change before their term of office ended. Interestingly, some eradication commissioners were entangled in a legal case before they are designated as eradication leaders. Method of study applied is normative research within primary legal materials are Law number 30, 2002 and Law number 19, 2019. Beside, the study also applies conceptual approach for determining the exact community involvement model. Whereas there is only one article that can be the basic law of community involvement; Article 30 of Law Number 30, 2002. community involvement as regulated in paragraph (6) only gives a respond on names of eradication commisioner candidates publicly announced by selection committee. In the other side, community involvement can be very strategic when it is implemented by using appropriate model. Community involvement will also give impact to community support. Implementation of community involvement in the matter of time and format become more and more important. Public test on eradication commissioner candidates will be an alternative model of community involvement in order to examine the eligibility.
\end{abstract}

Keywords: Public Test, Commissioners, Community Involvement.

\begin{abstract}
Abstrak
Penelitian bertujuan untuk menemukan model pelibatan masyarakat dalam seleksi komisioner KPK. Hal ini dianggap penting mengingat hasil seleksinya menimbulkan pro dan kontra di masyarakat, termasuk hasil seleksi komisioner KPK periode 2019-2023. Sementara seleksi komisioner KPK sebelumnya juga terdapat catatan menarik. Dua periode diantaranya (periode 2007-2011 dan periode 20112015) beberapa pimpinan KPK terjerat kasus hukum yang berakibat adanya pergantian sebelum masa jabatannya berakhir. Menariknya, beberapa pimpinan KPK itu terjerat kasus hukum yang terjadi sebelum yang bersangkutan ditetapkan sebagai pimpinan KPK. Metode penelitian yang digunakan yaitu metode penelitian normatif dengan bahan hukum primer yakni UU Nomor 30 Tahun 2002 dan UU Nomor 19 Tahun 2019. Selain menggunakan pendekatan perundang-undangan,
\end{abstract}


juga menggunakan pendekatan konsep guna menemukan model pelibatan masyarakat yang tepat. Bahwa terdapat satu pasal yang menjadi dasar hukum pelibatan masyarakat, yakni Pasal 30 UU Nomor 30 Tahun 2002. Pelibatan masyarakat yang dimaksud diatur pada ayat (6) hanya sebatas memberikan tanggapan saat nama calon komisioner diumumkan ke publik oleh panitia seleksi. Padahal keterlibatan masyarakat menjadi strategis jika dilaksanakan dengan model yang tepat. Pelibatan masyarakat akan berdampak pada dukungan masyarakat. Mempertegas format dan waktu pelibatan masyarakat sangat penting. Uji publik terhadap calon pimpinan KPK menjadi alternatif model keterlibatan masyarakat untuk mengetahui kelayakannya.

Kata Kunci: Uji Publik, Komisioner, Pelibatan Masyarakat.

\section{Pendahuluan}

Lembaga Negara yang diberi kewenangan melakukan pemberantasan tindak pidana korupsi yakni Komisi Pemberantasan Korupsi (KPK) akhirnya dibentuk oleh Negara Indonesia pada tahun 2002. Lembaga ini kehadirannya dikehendaki oleh masyarakat dan diyakini menjadi bagian penting untuk mewujudkan agenda reformasi. Dukungan juga diberikan oleh MPR (Majelis Permusyawaratan Rakyat). Tepatnya pada tanggal 13 November 1998 MPR menetapkan Ketetapan MPR RI Nomor XI/MPR/1998 Tentang Penyelenggara Negara yang Bersih dan Bebas Korupsi, Kolusi dan Nepotisme.

Komitmen pemberantasan korupsi menjadi solusi untuk keluar dari keterpurukan dan menjadi modal guna menyongsong Indonesia baru. Tindak lanjut dari Ketetapan TAP MPR RI terwujud dalam beberapa peraturan perundang-undangan yang pada akhirnya menjadi dasar hukum pembentukan lembaga pemberantas korupsi yang dikenal dengan sebutan KPK.

Rakyat menaruh harapan besar dengan terbentuknya KPK. Tentu harapan yang wajar bagi sebuah lembaga yang pembentukannya akibat dari ketidakpercayaan rakyat atas lembaga-lembaga penegak hukum yang sudah ada sebelumnya. Lembaga-lembaga penegak hukum, seperti kejaksaan dan kepolisian dianggap sudah tidak mampu untuk menegakkan hukum khususnya terkait dengan kejahatan korupsi. Oleh karenanya, KPK dibentuk sebagai lembaga alternatif yang dapat 
menjawab harapan rakyat, yakni pemberantasan korupsi.

Sejak tahun 2003 hingga saat ini, lembaga KPK telah memasuki lima periode kepemimpinan dengan berbagai rintangan-rintangan yang harus dihadapi untuk menegakkan hukum dan memberantas korupsi. Diantara rintangannya yaitu beberapa pimpinan KPK terjerat kasus hukum. Beberapa pimpinan KPK periode 2007-2011 dan periode 2011-2015, beberapa diantaranya terjerat kasus hukum yang berakibat adanya pergantian sebelum masa jabatannya berakhir. Peristiwa yang sudah barang tentu akan menghambat proses-proses pemberantasan korupsi. Terjeratnya pimpinan KPK dalam kasus hukum ini juga mendapat perhatian dari berbagai lapisan masyarakat. Bahkan masyarakat beranggapan bahwa peristiwa tersebut sebagai peristiwa kriminalisasi terhadap pimpinan KPK. Anggapan demikian terbangun atas dasar bahwa kasus-kasus yang dituduhkan pada pimpinan KPK adalah kasus-kasus yang telah terjadi jauh sebelum yang bersangkutan ditetapkan sebagai pimpinan KPK.
Seharusnya terjeratnya beberapa pimpinan KPK dengan persoalan hukum masa lalu menjadi perhatian serius tim seleksi agar hal tersebut tidak terulang dimasa depan. Memaksimalkan pelibatan masyarakat dalam proses seleksi menjadi penting bagi tim seleksi guna mendapatkan informasi secara komprehensif terkait para calon pimpinan KPK. Pelibatan masyarakat juga bermanfaat dalam membangun komitmen masyarakat untuk membantu penerapan suatu keputusan yang telah dibuat (Muluk, 2010). Komitmen ini merupakan modal utama bagi keberhasilan sebuah implementasi kebijakan (Muluk, 2010). Keterlibatan masyarakat dalam proses seleksi calon pimpinan KPK sebagai upaya menghindari terjeratnya pimpinan KPK dengan kasus-kasus hukum masa lalu. Pelibatan masyarakat pada proses seleksi pimpinan KPK selain dapat mengetahui rekam jejak secara lebih mendalam, juga pimpinan terpilih akan dapat dukungan publik pada agenda pemberantasan korupsi. Dukungan publik terbukti telah menjadi kekuatan nyata ketika 
lembaga KPK menghadapi berbagai peristiwa yang mengancam eksistensinya sebagai lembaga pemberantas korupsi. Dukungan publik terhadap KPK telah dibuktikan dalam berbagai peristiwa, diantaranya pada saat peristiwa cicak lawan buaya dan yang masih segar di ingatan adalah dukungan rakyat ketika terjadi peristiwa yang diduga sebagai peristiwa kriminalisasi terhadap pimpinan KPK yang berujung pada pemberhentian sementara terhadap Bambang Wijoyanto dan Abraham Samad.

Keterlibatan publik dalam proses seleksi calon pimpinan (komisioner) KPK layak mendapatkan perhatian. Keterlibatan publik dapat menjadi alternatif guna membantu tim seleksi, terutama terkait informasi rekam jejak para calon pimpinan. Ironinya, hingga proses seleksi tahun 2019, keterlibatan masyarakat tidak jelas dan tegas baik format maupun waktunya. Padahal secara normatif (Undang-Undang Nomor 30 Tahun 2002) tim seleksi memiliki kewajiban untuk melibatkan masyarakat. Pelibatan masyarakat juga akan berdampak pada dukungan masyarakat. Apalagi dalam kondisi dimana banyak upaya pelemahan KPK. Beberapa peristiwa sebagai gerakan untuk melemahkan KPK terjadi baik dari segi kelembagaan maupun dari regulasinya. Kelembagaannya seperti penetapan tersangka beberapa pimpinan KPK. Sementara secara regulasi terdapat hasil revisi Undang-Undang Nomor 30 Tahun 2002 yang terumuskan dalam Undang-Undang Nomor 19 tahun 2019.

Sementara tindak pidana korupsi di Indonesia masih memprihtinkan. Berbagai lembaga atau organisasi di luar negeri baik swasta maupun pemerintah juga berpendapat bahwa fenomena korupsi di Indonesia sudah sangat parah. Hal ini ditunjukkan antara lain dari berbagai hasil survey atau penelitian yang mereka lakukan dan dibandingkan dengan kondisi diberbagai Negara lainnya, antara lain seperti hasil penelitian dari PERC (Political and Economic Risk Consultancy, 2000) yang menempatkan Indonesia sebagai Negara dengan tingkat korupsi tertinggi dan sarat kroniisme dengan skor 9,91untuk korupsi, dan 9,09 
untuk kroniisme diantara Negaranegara Asia,dengan skala penilaian yang sama antara nol yang terbaik hingga sepuluh yang terburuk (Jeddawi, 2011).

Proses beberapa kali seleksi calon pimpinan KPK yang menimbulkan permasalahan menjadi alasan utama pentingnya kajian ini. Bahwa belum adanya kepastian pengaturan mengenai format dan waktu pelibatan masyarakat menjadi salah satu kelemahan pengaturan yang ada. Padahal, ketika ada keterlibatan masyarakat, maka akan terdapat proses secara terbuka, termasuk terkait dengan kelayakan dari masing-masing calon pimpinan KPK yang perlu mendapatkan perhatian secara sungguh-sungguh dari masyarakat. Untuk itu, membuka ruang atau kesempatan bagi masyarakat menjadi hal yang penting. Dengan demikian, terbuka kesempatan bagi tim seleksi untuk mendapatkan segala informasi, terutama informasi masa lalu yang sulit terjangkau oleh tim seleksi. Menjadi kewajiban bagi tim seleksi mempelajari masa lalu dari masingmasing pendaftar. Tim seleksi harus memastikan hasil seleksi terbebas dari catatan tercela yang berpotensi menjadi perbuatan melawan hukum.

Oleh karena itu, dalam kajian ini membahas satu rumusan permasalahan yakni bagaimanakah model pelibatan masyarakat dalam proses seleksi komisioner KPK? Yang dimaksud pelibatan masyarakat dalam kajian ini adalah sama dengan partisipasi publik atau masyarakat. Dimana partisipasi diartikan sebagai ikut serta, berperan serta dalam suatu kegiatan, mulai dari perencanaan sampai dengan evaluasi (Sirajuddin, 2011).

\section{Metode Penelitian}

Dalam mengkaji rumusan permasalahan ini digunakan metode penelitian normatif. Sebagai bahan hukum primernya yakni UndangUndang Nomor 30 Tahun 2002 dan Undang-Undang Nomor 19 Tahun 2019.

Obyek penelitian diteliti melalui metode penelitian hukum normatif dengan beberapa pendekatan. Pertama, pendekatan perundangundangan adalah dilakukan dengan cara menelaah peraturan perundang- 
undangan yang berkaitan dengan masalah hukum yang dikaji. Kedua, pendekatan analitis (analytical approach), pendekatan ini dilakukan dengan mencari makna atau istilahistilah hukum yang terdapat dalam peraturan perundang-undangan, dengan begitu peneliti memperoleh pengertian/ pemahaman atau makna baru dari istilah-istilah hukum.

Pada penelitian ini metode pengumpulan bahan hukum menggunakan studi kepustakaan. Kemudian bahan hukum yang sudah diperoleh dianalisa. Metode analisis dalam penelitian ini menggunakan analisis deskriptif. Melalui analisis deskriptif peneliti memberikan gambaran atau paparan atas objek penelitian sebagaimana hasil penelitian yang dilakukan.

\section{Hasil dan Pembahasan}

\section{A) Proses Seleksi Komisioner Komisi Pemberantasan Korupsi (KPK)}

Proses seleksi calon komisioner KPK diatur dalam Undang-Undang Nomor 30 Tahun 2002 tentang Komisi Pemberantasan Tindak Pidana Korupsi. Khusus pengaturan yang menjadi dasar hukum proses seleksi diatur dalam Pasal 30 dan Pasal 31 Undang-Undang Nomor 30 Tahun 2002. Pasal 30 yang terdiri dari 13 (tiga belas) ayat mengatur mengenai tahapan-tahapan seleksi calom pimpinan KPK.

Bahwa dari tiga belas ayat dalam Pasal 30 itu hanya terdapat tiga ayat yang dapat dikatakan langsung berhubungan dengan keterlibatan masyarakat. Pertama, ayat (3) Pasal 30 yang rumusannya sebagai berikut: "Keanggotaan panitia seleksi sebagaimana dimaksud pada ayat (2) terdiri atas unsur pemerintah dan unsur masyarakat". Berdasarkan ayat (3) tersebut, bahwa pemerintah ketika membentuk Panitia Seleksi ada keharusan untuk menempatkan perwakilan dari. Jadi, Keanggotaan pansel terdiri dari unsur pemerintah dan unsur masyarakat. Namun tidak ada pengaturan lebih lanjut mengenai kriteria atau batasan-batasan tentang masyarakat yang dapat dilibatkan dalam panitia seleksi. Sehingga dalam implementasinya, semua kembali kepada pembentuk panitia seleksi, yakni Presiden. Sebagai catatan saja bahwa unsur dari 
masyarakat pada tim seleksi untuk pimpinan KPK periode 2019-2023 dipertanyakan oleh masyarakat. Hanya saja, ternyata peristiwa ini tidak menjadi pertimbangan atau perhatian bagi Presiden dan DPR pada saat proses revisi undangUndang Nomor 30 Tahun 2002.

Kedua, Pasal 30 ayat (6) yang rumusannya sebagai berikut: "Panitia seleksi mengumumkan kepada masyarakat untuk mendapatkan tanggapan terhadap nama calon sebagaimana dimaksud pada ayat (4)". Isi dari ayat (6) menghendaki agar dibuka kesempatan bagi masyarakat untuk memberikan tanggapan terhadap nama-nama calon pimpinan KPK. Bagi masyarakat yang berkenan memberikan tanggapan dapat disampaikan kepada panitia seleksi paling lambat satu bulan terhitung sejak tanggal diumumkan. Sebagaimana diatur dalam Pasal 30 ayat (7) yang menyatakan bahwa "Tanggapan sebagaimana dimaksud pada ayat (6) disampaikan kepada panitia seleksi paling lambat 1 (satu) bulan terhitung sejak tanggal diumumkan”.
Ketiga ayat dalam Pasal 30 Undang-Undang Nomor 30 tahun 2002 yang bersinggungan dengan keberadaan masyarakat dalam proses seleksi pimpinan KPK masih jauh dari kata ideal. Ketidakjelasan pengaturan kriteria yang disebut masyarakat untuk mewakili unsur masyarakat sebagaimana Pasal 30 ayat (3). Ujung-ujungnya kembali kepada Presiden sebagai pihak yang diberi kewenangan oleh UndangUndang untuk membentuk Panitia Seleksi. Ketika mekanisme penentuan siapa yang dapat mewakili sebagai unsur masyarakat, maka keterlibatan masyarakat dalam panitia seleksi menjadi bias. Hal itu disebabkan bahwa yang ditunjuk oleh Presiden untuk mengisi unsur masyarakat sebagaimana yang telah ditentukan oleh Pasal 30 ayat (3) belum tentu benar-benar mewakili masyarakat.

Catatan perlu juga diberikan untuk Pasal 30 ayat (6) dan ayat (7). Jika diilihat rumusannya, bahwa kewajiban panitia hanya sebatas memberikan pengumuman kepada masyarakat. Setelah pengumuman sudah dilakukan oleh panitia seleksi, maka selanjutnya menjadi hak dari 
masyarakat apakah akan memberikan tanggapan ataukah tidak. Bahwa keharusan untuk mendapatkan tanggapan dari masyarakat tidak ada aturannya. Panitia seleksi dengan demikian dapat melaksanakan tahapan berikutnya meski seandainya saja sama sekali tidak ada tanggapan dari masyarakat terhadap para calon pimpinan KPK. Sehingga Pasal 30 ayat (6) tidak dapat menjadi dasar hukum atau dengan kata lain tidak dapat disebut pelindung keterlibatan masyarakat dalam proses seleksi. Begitu juga ketika terdapat tanggapan masyarakat, masyarakat juga tidak dapat mengetahui apakah tanggapan tersebut digunakan atau diperhatikan oleh tim seleksi atau tidak. Hal itu dikarenakan tidak ada pengaturan mengenai keharusan tim seleksi menyampaikan secara terbuka kepada publik semua tanggapan yang masuk ke tim seleksi.

Biasnya pengaturan tentang keterlibatan masyarakat dalam proses seleksi pimpinan KPK juga nampak jelas dalam rumusan Pasal 30 ayat (7). Batas waktu untuk memberikan tanggapan hanya dalam waktu satu bulan terhitung sejak nama-nama calon pimpinan KPK diumumkan. Hitungan satu bulan tersebut tidak mempertimbangkan hari libur atau hari kerja. Begitu juga soal mekanisme untuk menyampaikan tanggapan juga tidak diatur dan tidak tersosialisasi secara baik. Dengan demikian bahwa Pasal 30 ayat (7) hanya menegaskan biasnya keterlibatan masyarakat.

Berikutnya, menelaah Pasal 31 Undang-Undang Nomor 30 Tahun2002. Rumusan pasal tersebut adalah sebagai berikut: "Proses pencalonan dan pemilihan anggota Komisi Pemberantasan Korupsi sebagaimana dimaksud dalam Pasal 30 dilakukan secara transparan". Bahwasanya Pasal 31 mengharuskan adanya proses yang transparan. Proses seleksi dilakukan dengan memegang prinsip keterbukaan. Sesungguhnya secara substansi Pasal 31 mempunyai makna penting dan strategis khususnya bagi keterlibatan masyarakat. Tanpa ada keterbukaan, sudah barang tentu masyarakat akan menemui kesulitan untuk memberikan tanggapan atau keterlibatan lainnya. 
Jadi, keberpihakan atas
keterlibatan masyarakat yang
tertuang dalam Pasal 30 dan Pasal 31
Undang-Undang Nomor 30 Tahun 2002 masih banyak kelemahan.

Sudah barang tentu kelemahan dari segi substansi ini akan mempengaruhi implementasinya. Bahwa peraturan perundang-undangan agar dapat diimplementasikan, maka bagi pembentuk sejak awal proses perancangan, dituntut mampu memenuhi berbagai kebutuhan, yakni: pertama, mampu dilaksanakan; kedua, dapat ditegakkan; ketiga, sesuai dengan prinsip-prinsip jaminan hukum dan persamaan hak-hak sasaran yang diatur; dan keempat, mampu menyerap aspirasi masyarakat (Syaifudin, 2009). Ditegaskan oleh Bagir Manan, agar pembentukan undang-undang menghasilkan suatu undang-undang yang tangguh dan berkualitas, dapat digunakan tiga landasan dalam menyusun undangundang, yaitu: pertama, landasan yuridis (juridische gelding); kedua, landasan sosiologis (sociologische gelding); dan ketiga, landasan filosofis. Pentingnya ketiga unsur landasan pembentukan undangundang tersebut, agar undang-undang yang dibentuk, memiliki kaidah yang sah secara hukum (legal validity), dan mampu berlaku efektif karena dapat atau akan diterima masyarakat secara wajar, serta berlaku untuk waktu yang panjang (Manan, 1994).

Ketika Undang-Undang Nomor 30 Tahun 2002 direvisi (sehingga terbit Undang-Undang Nomor 19 tahun 2019) ternyata tidak merubah pengaturan yang terkait dengan pelibatan masyarakat dalam proses seleksi calon pimpinan KPK. Proses terbentuknya Undang-Undang Nomor 19 Tahun 2019 mendapatkan kritik,protes dan gugatan ke Mahkamah Konstitui. Undangundang tersebut dianggap telah mengabaikan masyarakat atau dengan kata lain bahwa masyarakat tidak dilibatkan. Padahal, ketika Negara meskipun dari sisi suprastruktur yang memiliki kewenangan untuk membuat hukum, namun jika itu dilakukan dengan mengabaikan pelibatan masyarakat maka tidak akan mendapatkan tempat yang cukup atau memadai (adequate) dalam proses demokratisasi (Hakim, 2011). 
Proses revisi Undang-undang yang mengabaikan partisipasi masyarakat jelas bertentangan dengan peraturan perundang-undangan dan bertentangan juga dengan semangat reformasi. Seharusnya pembangunan hukum nasional masa reformasi merupakan konsekuensi sistem demokrasi yang menuntut transparansi, akuntabilitas, mengedepankan hak asasi manusia serta membuka akses informasi publik ke dalam birokrasi (Atmasasmita, 2012).

Sehingga kualitas undangundang yang dihasilkan bernilai baik. Suatu undang-undang dapat dikatakan baik dan bahkan memiliki karakteristik berkelanjutan, bisa dinilai dari sudut pandang keberhasilan mencapai tujuan (doeltreffendheid), pelaksanaan (uitvoerbaarheid) dan penegakan hukumnya (handhaafbaarheid) (Yuliandri, 2009). Proses penegakan hukum dipengaruhi oleh tiga faktor, yakni (Halim, 2009): pertama, faktor substansi hukum, yaitu aturan, norma, pola perilaku nyata manusia yang berbeda dalam sistem itu. Substansi juga berarti produk yang dihasilkan oleh orang yang berada dalam sistem hukum itu, mencakup keputusan yang mereka keluarkan, aturan baru yang mereka susun. Substansi juga mencakup living law (hukum yang hidup), dan bukan hanya aturan yang ada dalam kitab undang-undang. Kedua, faktor struktural dalam hal ini adalah bagian yang tetap bertahan, bagian yang memberi semacam bentuk dan batasan terhadap keseluruhan. Ketiga, faktor kultural, dalam hal ini sikap manusia dan sistem hokum kepercayaan, nilai pemikiran serta harapannya.

Terkait dengan faktor substansi hukum, M. Laica Marzuki sebagaimana yang kutip oleh Yuliandri, menjelaskan bahwa: "substansi hukum adalah seperangkat kaidah hukum (set of rules and norms), lazim disebut peraturan perundang-undangan. Substansi hukum tidak hanya mencakupi pengertian kaidah hukum tertulis (written law), tetapi termasuk kaidahkaidah hukum kebiasaan (adat) yang tidak tertulis (Yuliandri, 2009). Hukum dan peraturan perundangundangan yang berlaku tidak boleh ditetapkan dan diterapkan secara 
sepihak oleh dan atau hanya untuk kepentingan penguasa. Hal ini bertentangan dengan prinsip demokrasi. Hukum tidak dimaksudkan hanya menjamin kepentingan beberapa orang yang berkuasa, melainkan menjamin kepentingan keadilan bagi semua orang.

Berdasarkan pandangan dari para ahli, maka rumusan pasal-pasal yang mengatur tentang keterlibatan masyarakat belum memungkinkan untuk menjamin terlaksananya keterlibatan masyarakat secara sungguh-sungguh. Ruang keterlibatan yang tidak tegas tentu akan mempengaruhi hasil dari semua proses yang telah dilaksnakan. Padahal, dukungan masyarakat untuk lembaga pemberantas korupsi (KPK) memiliki makna penting dan strategis. Apalagi kelahiran dari lembaga ini atas kehendak dari masyarakat yang tertuang dalam agenda reformasi. Dukungan masyarakat juga terbukti menjadi benteng terakhir ketika lembaga KPK mendapatkan serangan dari mereka yang merasa kepentingannya terganggu dengan keberadaan KPK.
Mereka yang tidak pro dengan KPK berupaya melakukan pelemahan. Berbagai upaya pelemahan itu dilakukan baik terhadap kelembagaannya maupun terhadap regulasi yang menjadi dasar berdirinya KPK.

\section{B) Uji Publik Sebagai Model Keterlibatan Masyarakat Dalam Proses Seleksi Komisioner KPK}

Pada sub bab sebelumnya sudah kita telaah bersama mengenai kelemahan-kelemahan pengaturan tentang keterlibatan masyarakat dalam proses seleksi calon pimpinan KPK. Keterlibatan masyarakat harus dimaknai sebagai sesuatu yang bukan hanya sebatas hak, akan tetapi juga harus menjadi kewajiban bagi semua pihak untuk melihat secara nyata keterlibatan masyarakat. Unsur keterlibatan masyarakat secara nyata akan berdampak pada hasil seleksi. Ketika masyarakat terlibat secara aktif, sudah barang tentu akan ada masukan-masukan yang jauh lebih mendalam, termasuk dalam hal rekam jejak dari para calon pimpinan KPK.

Pengalaman kepemimpinan KPK pada periode sebelumnya dimana 
para pimpinan KPK terjerat kasus hukum masa lalu (terjerat kasus hukum sebelum yang bersangkutan menjabat sebagai pimpinan KPK). Terlepas dari apakah peristiwa itu semata-mata peristiwa kriminalisasi atau peristiwa hukum yang sebenarnya. Yang jelas, bahwa peristiwa tersebut telah mengganggu proses penegakan dan pemberantasan tindak pidana korupsi. Kalau pimpinan yang dihasilkan ternyata memiliki persoalan hukum masa lalu, tentu akan menjadi beban selama yang bersangkutan menjabat sebagai pimpinan lembaga pemberantas korupsi. KPK juga akan terganggu independensinya ketika dipimpin oleh orang yang tidak bersih dari persoalan hukum.

Prakteknya, independensi suatu lembaga dapat dipengaruhi oleh beberapa hal, antara lain: a) bagaimana mandate yang kuat diberikan kepada lembaga tersebut; b) bagaimana UU bersangkutann memungkinkan pembentukan lembaga yang kuat dalam menjalankan mandate yang diberikan; c) bagaimana lembaga tersebut diisi oleh orang-orang yang memiliki kapasitas dan integritas yang baik (Yuliandri, 2009). Jadi, proses seleksi yang dilakukan oleh panitia seleksi harus menghasilkan orang yang memiliki kapasitas dan integritas yang baik.

Apalagi sejarah terbentuknya KPK adalah untuk menjawab kebuntuan upaya pemberantasan korupsi dari lembaga kejaksaan dan kepolisian. Kedua lembaga penegak hukum tersebut kesulitan menjalankan perannya karena terbebani dengan oknum-oknum di internal lembaga yang tidak bersih. KPK sebagai alat perlengkapan Negara state auxiliaries mempunyai kewajiban untuk membuktikan kepada publik sebagai lembaga penegak hukum yang berbeda dengan lembaga kejaksaan dan kepolisian. Secara umum alat perlengkapan Negara yang berupa state auxiliaries atau independent bodies ini muncul karena (Nurtjahjo, 2005):

a) Adanya tugas-tugas kenegaraan yang semakin kompleks yang memerlukan independensi yang cukup untuk operasionalisasinya.

b) Adanya upaya empowerment terhadap tugas lembaga Negara 
yang sudah ada melalui cara membentuk lembaga baru yang lebih spesifik.

Keterlibatan masyarakat dapat menjadi alternatif guna membantu tim seleksi, terutama terkait informasi rekam jejak para calon pimpinan. Ironinya, hingga proses seleksi tahun 2015 ini keterlibatan masyarakat tidak jelas dan tegas baik format maupun waktunya. Padahal secara normatif (Undang-Undang Nomor 30 Tahun 2002) tim seleksi memiliki kewajiban untuk melibatkan masyarakat. Pelibatan masyarakat juga akan berdampak pada dukungan masyarakat. Apalagi dalam kondisi dimana banyak upaya pelemahan KPK. Beberapa peristiwa sebagai gerakan untuk melemahkan KPK terjadi baik dari segi kelembagaan maupun dari regulasinya. Kelembagaannya seperti penetapan tersangka beberapa pimpinan KPK. Sementara secara regulasi terdapat tuntutan merevisi regulasi yang selama ini menjadi payung hukum bagi KPK.

Jika kita belajar dalam catatan sejarah, ternyata lembaga pemberantas korupsi di negeri ini sudah berulang kali dibentuk. Bahkan era orde lama dan era orde baru juga membentuk lembaga yang khusus untuk pemberantasan korupsi. Hanya saja, lembaga-lembaga yang dibentuk jauh sebelum KPK itu independensi dan efektifitasnya dipertanyakan banyak pihak. Berikut ulasan singkat mengenai perjalanan Negara dalam upayanya memberantas korupsi. Pada masa orde lama (“Operasi Budhi”) Munculnya Perppu tentang pengusutan, penuntutan dan pemeriksaan tindak pidana korupsi. Perpu itu lalu dikukuhkan menjadi Undang-Undang Nomor 24 Tahun 1960. Salah satu upaya yang dilakukan adalah melancarkan “Operasi Budhi”, khususnya untuk mengusut karyawan-karyawan ABRI yang dinilai tidak becus. Waktu itu perusahaan-perusahaan Belanda diambil-alih dan dijadikan BUMN, dipimpin oleh para perwira TNI. “Operasi Budhi” antara lain mengusut Mayor Suhardiman (kini Mayjen TNI Pur) meskipun akhirnya dibebaskan dari dakwaan.

Pada masa orde baru dibentuk Tim Pemberantasan Korupsi akhir tahun 1967 oleh Presiden Soeharto. 
Pembentukannya dengan Keputusan

Presiden Nomor 228 Tahun 1967.

Dasar hukumnya tetap mengacu pada Undang-Undang Nomor 24 Tahun 1960. Para anggota tim ini merangkap jabatan lain seperti Jaksa Agung, Kapolri, Menteri Kehakiman, dan Panglima ABRI. Hasil kerja tim adhoc ini kemudian berhasil menyeret Sembilan orang yang diindikasikan koruptor.

Presiden Soeharto juga membentuk sebuah wadah yang disebut Komisi empat pada tahun 1970. Wadah ini diibentuk dalam rangka untuk memberikan penilaian obyektif terhadap langkah yang telah diambil pemerintah dan memberikan pertimbangan mengenai langkah yang lebih efektif untuk memberantas korupsi. Mantan Wakil Presiden M. Hatta diangkat sebagai penasihat Komisi Empat. Anggota-anggotanya adalah mantan perdana menteri Wilopo, I.J.Kasimo, Prof. Johannes dan Anwar Tjokroaminoto dan Kepala BAKIN Mayjen Sutopo Yuwono menjadi sekretaris.

Selama periode 1970-1977 hanya satu pejabat tinggi yang dipenjara karena korupsi, yaitu Deputi Kapolri
Letjen Pol Siswadji. Pegawai negeri yang diganjar hukuman paling berat adalah Kepala Depot Logistik Kaltim Budiadji, yang divonis penjara seumur hidup (grasi Presiden menguranginya menjadi 20 tahun). Selebihnya yang dihukum adalah para koruptor lapis kedua dan rendahan bahkan sedikit sekali pelaku tindak pidana korupsi yang diajukan di pengadilan. Banyak kasus yang dipetieskan atau tidak diketahui kelanjutannya secara jelas.

Dibawah Presiden Soeharto terbentuk juga sebuah lembaga yang diberi nama Komisi Anti Korupsi (KAK). Berdiri Komisi Anti Korupsi pada tahun 1970. Anggotanya terdiri dari aktivis mahasiswa eksponen 66 seperti Akbar Tanjung, Thoby Mutis, Asmara Nababan. Namun belum terlihat hasil yang telah dicapai, 28 Komisi ini dibubarkan pada 15 Agustus 1970 atau hanya dua bulan sejak terbentuk. Setelah itu Presiden Soeharto membuat kebijakan yang dikenal dengan sebutan Operasi Penertiban (OPSTIB). Dasar pembentukannya berupa Inpres 9 Tahun 1977. 
Pemerintah melancarkan Operasi Penertiban (OPSTIB). Dalam empat tahun (1977- 1981) Opstib telah menyelamatkan uang negara Rp. 200 milyar dan menindak 6.000 pegawai. Opstib merupakan gabungan dari unsur polisi, kejaksaan, militer, dan dari menteri pendayagunaan aparatur negara dan setiap tiga bulan melaporkan kepada Presiden tentang penertiban di departemen dan jawatan pemerintah.

Sementara pada era reformasi beberapa kali juga dibentuk sebuah lembaga yang dimaksudkan untuk memberantas korupsi. Terlebih, pemberantasan korupsi merupakan salah satu agenda reformasi yang digelorakan oleh masyarakat. Pada era Presiden Abdurrahman Wahid terlahir sebuah wadah yang diberi nama Tim Gabungan Pemberantasan Tindak Pidana Korupsi (TGPTPK). Tim ini berada di bawah Jaksa Agung Marzuki Darusman. TGPTPK dibentuk sebagai lembaga sementara sampai terbentuknya Komisi Pemberantasan Korupsi yang merupakan amanat Undang-Undang Nomor 31 tahun 1999 tentang pemberantasan korupsi. Sayang,
TGPTPK yang beranggotakan jaksa, polisi dan wakil dari masyarakat tidak mendapat dukungan. Bahkan oleh Jaksa Agung sendiri. Permintaan TGPTPK untuk mengusut kasus BLBI yang banyak macet prosesnya ditolak oleh Jaksa Agung. Akhirnya, TGPTPK dibubarkan tahun 2001 ketika gugatan judicial review tiga orang Hakim Agung pernah diperiksa oleh TGPTPK dikabulkan oleh Mahkamah Agung.

Pada tahun 1999 juga pernah terbentuk Komisi Pemeriksa Kekayaan Penyelenggaran Negara (KPKPN) berdasarkan UndangUndang Nomor 28 Tahun 1999 tentang Penyelenggaraan Pemerintahan yang bersih dan bebas dari korupsi, kolusi dan nepotisme. Komisi yang dipimpin oleh Yusuf Syakir ini bertugas menerima dan memeriksa laporan kekayaan para penyelenggara negara. Sejumlah pejabat pernah dilaporkan oleh KPKPN ke Kepolisian, namun banyak kasus yang tidak ditindaklanjuti seperti kasus kepemilikan rumah dan tanah yang tidak dilaporkan milik Jaksa Agung waktu itu, MA Rachman. 
Berdasarkan Undang-Undang Nomor 30 Tahun 2002 tentang KPK akhirnya KPKPN dilebur menjadi bagian KPK. Upaya terakhir mempertahankan KPKPN melalui permohonan Judicial Review akhirnya ditolak oleh Mahakamah Konstitusi. Komisi Pemberantasan Korupsi (KPK) Pada era Megawati sebagai Presiden. Terbentuk berdasarkan Undang-Undang Nomor 30 Tahun 2002 tentang Komisi Pemberantasan Tindak Pidana Korupsi. Komisi superbody yang memiliki 5 tugas dan 29 wewenang yang luar biasa ini dipimpin oleh Taufiqurahman Ruki, Sirajudin Rasul, Amien Sunaryadi, Erry Riyana Harjapamengkas, Tumpak Hatorang.

Belum genap satu tahun berdiri, KPK telah menerima 1.452 laporan masyarakat mengenai praktek korupsi. Sepuluh kasus diantaranya ditindaklanjuti dalam proses penyidikan dan sudah dua kasus korupsi yang berhasil dilimpahkan ke Pengadilan Tipikor (Abdullah Puteh dan Harun Let Let dan keduanya telah divonis). Kasus korupsi besar yang telah ditangani KPK adalah korupsi yang terjadi di Komisi Pemilihan
Umum (KPU). Hasil 30 penyelidikan dan penyidikan KPK berhasil menjebloskan ketua dan anggota KPU serta beberapa pegawai Setjen KPU ke penjara. Meskipun seringkali menuai kritik dari berbagai kalangan namun apa yang telah dilakukan oleh KPK sedikit banyak memberikan harapan bagi upaya penuntasan beberapa kasus korupsi di Indonesia.

Setelah Megawati lengser dan digantikan oleh Presiden Susilo Bambang Yudhoyono (SBY), program 100 hari pemerintahannya ditandai dengan pembentukan Tim Pemburu Koruptor yang dipimpin oleh oleh Wakil Jaksa Agung, Basrief Arief dibawah koordinasi Wakil Presiden Jusuf Kalla. Tim yang terdiri dari Kejaksaan dan Kepolisian bertugas memburu terpidana dan tersangka kasus korupsi yang melarikan diri keluar negeri. Meskipun belum terlihat hasil yang telah dicapai, namun Tim Pemburu koruptor diberitakan sudah menurunkan tim ke lima negara, yaitu Singapura, Amerika Serikat, Hongkong, Cina dan Australia. Selain itu Tim pemburu koruptor juga telah mengidentifikasi jumlah aset yang 
terparkir di luar negeri sebanyak 6-7 triliun rupiah.

Yang terakhir dibentuk adalah Tim Koordinasi Pemberantasan Tindak Pidana Korupsi (Timtas Tipikor) yang dibentuk Presiden Susilo Bambang Yudhoyono (SBY) berdasarkan Keputusan Presiden Nomor 11 Tahun 2005 pada tanggal 2 Mei 2005. Ada dua tugas utama yang diemban tim yang diketuai oleh Hendarman Supandji. Pertama, melakukan penyelidikan, penyidikan dan penuntutan sesuai dengan ketentuan hukum acara yang berlaku terhadap kasus dan/atau indikasi tindak pidana korupsi. Kedua, mencari dan menangkap pelaku yang diduga keras melakukan tindak pidana serta menelusuri asetnya dalam rangka pengembalian keuangan secara optimal.

Masa tugas Tim yang terdiri dari 48 orang anggota dan berasal dari unsur kepolisian, kejaksaan dan BPKP adalah dua tahun dan dapat diperpanjang. Tim ini berada dan bertanggung jawab langsung kepada Presiden. Setiap tiga bulan, timtas tipikor melaporkan perkembangan kerjanya kepada Presiden. Tidak lama setelah berdiri, tim ini sudah disibukkan dengan penyelesaian kasus korupsi yang terjadi di 16 badan usaha milik negara (BUMN), 4 Departemen, 3 perusahaan swasta dan 12 koruptor yang melarikan diri. Berbeda dengan Komisi Pemberantasan Korupsi yang telah menentukan adanya kriteria kasus korupsi yang dapat langsung ditangani oleh komisi, dalam Kepres Nomor 11 Tahun 2005 yang menjadi dasar hukum keberadaan Timtas Tipikor tidak menyebutkan kriteria kasus apa saja yang menjadi kewenangannya.

Berdasarkan uraian tentang lembaga pemberantas korupsi dari era orde lama hingga era reformasi, beberapa pelajaran menarik dapat diambil. Bahwa diantara sekian banyak lembaga yang pernah dibentuk, ternyata hanya KPK yang memiliki independensi dan kewenangan yang luar biasa. Hanya KPK pula yang dapat bertahan paling lama jika dibandingkan dengan lembaga-lembaga lainnya.

Tentunya ada banyak faktor yang mempengaruhi eksistensi sebuah lembaga. Namun jika kita cermati 
bahwa selain KPK, ternyata ditemukan campur tangan pihak lain dalam menjalankan lembaga tersebut, termasuk Presiden pemegang pimpinan langsung untuk beberapa lembaga. Intervensi kekuasaan lain mempengaruhi sebuah keberadaan lembaga. Oleh karena itu mempertegas format dan waktu pelibatan masyarakat sangat penting. Uji publik terhadap para calon pimpinan KPK dapat menjadi alternatif format atau model keterlibatan masyarakat. Secara terbuka kelayakan dari masingmasing calon akan dipelajari dan diuji oleh publik. Dengan demikian, terbuka kesempatan bagi tim seleksi untuk mendapatkan segala informasi, terutama informasi masa lalu yang sulit terjangkau oleh tim seleksi.

\section{Simpulan}

Uji Publik dimaksudkan sebagai gagasan model yang akan memberikan ruang keterlibatan masyarakat dalam proses seleksi calon pimpinan KPK secara mendalam. Gagasan ini beranggkat dari pemahaman bahwa regulasi yaitu Undang-Undang Nomor 30 Tahun
2002 tentang Komisi Pemberantasan Tindak Pidana Korupsi, belum secara nyata mengatur keterlibatan masyarakat. Selain kelemahan isi dari regulasi, bahwa gagasan uji publik juga bermakna strategis untuk memperoleh dukungan masyarakat. Bahwasanya pemberantasan korupsi sudah harus menjadi komitmen bersama seluruh komponen. Uji publik harapannya dapat menjadi media membangun komitmen secara bersama-sama antara masyarakat dengan para calon pimpinan KPK.

Secara teknis, pelaksanaan dari uji publik ini sudah barang tentu membutuhkan kajian lanjutan agar diperoleh sebuah formula yang tepat dan efektif. Namun sebagai pemikiran awal, bahwa mekanisme debat terbuka dengan unsur masyarakat sebagai panelis atau jajak pendapat terbatas dapat dipertimbangkan. Yang jelas bahwa gagasan uji publik dimaksudkan sebagai pendobrak sebuah proses seleksi yang hingga saat ini tidak secara sungguh-sungguh menghadirkan masyarakat untuk terlibat. Padahal, secara historis bahwa lembaga KPK hadir benar- 
benar karena dukungan masyarakat. Begitu juga masyarakat selalu hadir secara sukarela ketika ada pihakpihak tertentu yang bermaksud mengancam dan membahayakan keberadaan lembaga KPK. Beberapa peristiwa yang diduga sebagai gerakan untuk melemahkan KPK terjadi baik dari segi kelembagaan maupun dari regulasinya. Kelembagaannya seperti penetapan sebagai tersangka terhadap beberapa pimpinan KPK Disinyalir sebagai gerakan pelemahan KPK (selanjutnya cari pendapat yg menyatakan demikian). Sementara secara regulasi terdapat tuntutan dari beberapa pihak untuk merevisi UU yang selama ini menjadi paying hokum bagi KPK. Peristiwa-peristiwa pelemahan tersebut yang mengiringi proses seleksi pimpinan KPK pada saat ini. Oleh karenanya momentum seleksi pimpinan KPK kali ini menarik untuk diperhatikan karena hasil seleksi kali ini yang akan sangat menentukan berhasil tidaknya untuk memastikan bahwa KPK terbebas dari ancaman pelemahan KPK.

Secara regulasi, ditemukan beberapa norma yang menarik untuk diperhatikan, khususnya yang berhubungan dengan penguatan KPK. Secara regulasi harus ada perlindungan bagi pimpinan KPK terbebas dari upaya-upaya kriminalisasi selama menjabat. Adanya norma yang telah mengatur tentang bahwa calon pimpinan itu harus terbebas dari perbuatan tercela dan juga harus jujur dan berintegritas, sehingga perlu ditegaskan kembali sebuah rumusan yang menjamin bahwa para calon pimpinan ketika sudah ditetapkan sebagai pimpinan KPK itu artinya sudah “clear" dari semua catatan perbuatan melawan hukum.

\section{Daftar Pustaka}

Buku

Abdul, Aziz, Hakim, 2011, Negara Hukum dan Demokrasi di Indonesia, Pustaka Pelajar, Yogyakarta.

Jimly, Asshiddiqie, 2010, Perkembangan dan Konsolidasi Lembaga Negara Pasca Reformasi, Sinar Grafika, Jakarta.

Khairul, Muluk, 2010, Menggugat Partisipasi Publik Dalam Pemerintahan Daerah,

Lukman, Hakim, 2010, Kedudukan Hukum Komisi Negara di Indonesia: Eksistensi 
Komisi-Komisi Negara

(State Auxiliary Agency)

Sebagai Organ Negara yang

Mandiri Dalam Sistem

Ketatanegaraan, Penerbit

Program Pascasarjana

Universitas Brawijaya,

Malang.

Murtir, Jeddawi, 2011, Negara Hukum, Good Governance, dan Korupsi di Daerah, Total Media, Yogyakarta.

Romli, Atmasasmita, 2012, Teori Hukum Integratif, Rekonstruksi Terhadap Teori Hukum Pembangunan dan Teori Hukum Progresif, Genta Publishing, Yogyakarta.

Sirajuddin, Didik Sukriono dan Winardi, 2011, Hukum Pelayanan Publik Berbasis Keterbukaan Informasi dan Partisipasi, Setara Press, Malang.

Yuliandri, 2009, Asas-Asas Pembentukan Peraturan Perundang-undangan Yang Baik, PT Rajagrafindo Persada, Jakarta.

\section{Undang-Undang}

Undang-Undang Republik Indonesia Nomor 30 Tahun 2002

Tentang Komisi Pemberantasan Tindak Pidana Korupsi.

Undang-Undang Republik Indonesia Nomor 19 Tahun 2019 Tentang Perubahan Kedua Atas Undang-Undang
Nomor 30 Tahun 2002

Tentang Komisi

Pemberantasan Tindak

Pidana Korupsi. 